\title{
The Augmentation of Existentialism: Robinson Crusoe's Character
}

\author{
Adama Bah \\ Department of Studies in English, University of Mysore, Mysore, Karnataka, India
}

\section{OPEN ACCESS}

Manuscript ID:

ENG-2020-08043354

Volume: 8

Issue: 4

Month: September

Year: 2020

P-ISSN: 2320-2645

E-ISSN: 2582-3531

Received: 20.06.2020

Accepted: 30.07.2020

Published: 01.09.2020

Citation:

Bah, Adama. "The

Augmentation of

Existentialism: Robinson

Crusoe's Character."

Shanlax International

Journal of English, vol. 8, no. 4, 2020, pp. 35-39.

DOI:

https://doi.org/10.34293/

english.v8i4.3354

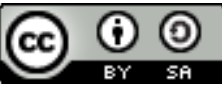

This work is licensed

under a Creative Commons Attribution-ShareAlike 4.0 International License

\section{Abstract}

The novel Robinson Crusoe by Daniel Defoe, theme depicts the philosophy of existentialism. Existentialism argues the existence of humans through freedom of choice of the existence of who or what to become. The Robinson Crusoe character's struggle to realize his freedom of life and defend his existence exemplars the existentialism. Robinson was adamant to his fathers' advice and went to the sea. This paper discusses the characteristics of existentialism evident in the novel Robinson Crusoe. These aspects include the essence of existence, existence precedes essence, human alienation or estrangement, Fear and Trembling Anxiety, The Encounter with Nothingness, and Freedom. The relationships between existence and freedom of choice in human life establish the fact on augmentation of existentialism, as seen in Robinson Crusoe Character.

Keywords: Existentialism, Being, Becoming, Freedom, Human existence, Human being and Nothingness

\section{Introduction}

Existentialism originates from 1813-1855 among philosopher's thinkers that relate it to focus on human existence. Spanish existentialist Miguel de Unamuno refers to existentialism as a subjective interpretation of life where the concern is on human existence in its identity. Existentialism is a philosophy of freedom and responsibility that liberates individuals' self-preservation and realization. It further values freedom as essential for human beings though it is limited.

Robinson Crusoe's main character in the novel Robinson Crusoe was an Englishman from New York in the seventeenth century, the youngest son of a merchant of German origin. Crusoe's father advised him to study law, but Crusoe opted to go to sea instead. His family was against Crusoe's decision, and his father explains that it is better to seek a modest, secure life for oneself.

Robinson Crusoe (2009) gives an account of Crusoe's dissatisfaction with competent studies he had received in preparation for a law career. $\mathrm{He}$ confessed that he is inclined to the sea. This made him act against his father's will, mother's and friend's persuasion. These show the inner human exercise of freedom to choose regardless of the advice and wish of the significant others. The decision of Robinson Crusoe to voyage in the sea without parents' approval emphasizes existence precedes essence.

The story of how Robinson Crusoe battled between individual follow of passion and his father's wish brings him to several decisions during difficulties at sea. In many circumstances and encounters, he entered a state of fear and trembling anxiety due to the confrontation of difficult situations at sea. The master of the sea advised him on opinion to heed to his fathers' suggestion to study law. Robinson's state of separation from the family, fellow men, society, God, and even himself brought feelings of alienation and estrangement. Crusoe, in several incidences would find himself repeatedly asking for forgiveness, making vows and resolutions. His character of retrieving back to the same 
activity of going to the sea when the situation appears to be safe leads Robinson to a state of nothingness. The point of encounter with nothingness forces man to exercises his freedom. The persistence of Robinson Crusoe to follow individual choice crown the components of existentialism philosophy, which include existence, alienation, estrangement, and nothingness. These components of existentialism are discussed with evidence-based on Robinson Crusoe's character in the novel Robinson Crusoe by Daniel Defoe.

\section{Existence precedes Essence}

Human existence is the most important aspect of humanity. Human nature of being "lacks" gives man the ability to be in the state of improving the way of life. The feeling of unsatisfied where there is ask for more something validates the existence. This gives humans to be in the state of "being" where humans" strife to improve to the betterment of reality (i.e.) becoming.

According to Kierkegaard, cited in Panjaitan (1996), it is true that the most important aspect of a human being is his existence, which is not the final. It is always in the process of becoming something better as he advances from possibility into reality. This process is possible because man has his autonomy. Therefore, human existence exists in freedom through actions. Emphasis is the availability of existence means having the courage to determine and decide one's own life. Robinson Crusoe's actions helped him to decide what to pursue in his life (Dagun, 1990:50).

\section{Alienation or Estrangement}

Human existence may not be without difficulties and problems. Existentialist argues that on a human encounter with challenges, they tend to alienate. To quote

"... convinced that modern man lives in a fourfold condition of alienation: from God, from nature, from other man and his true self" (Alssid. (1964), page:206).

Robinson Crusoe's alienation and estrangement from God, another man, nature, and himself, moreover he felt despair, powerless and hopeless for life when he went aground on a small island due to the raging wave, mountain-like, rammed into his ship. The boat overset once by sea wave separating passengers from one another. Crusoe emerged the only survivor after the master and all the passengers perished in the sea disaster. Crusoe came on the island 30th of September1659, after great difficulty and much effort where he lived alone for a long time (Robinson Crusoe, (2009), page: 68).

Alienation and estrangement bring man to feel empty, powerless, and faceless. The fact that he had no food and in a strange state made him hollow and hopeless. Robinson depicted when he wrote:

“...I, poor miserable Robinson Crusoe, being shipwrecked, during a dreadful storm, in the offing, came onshore in this dismal unfortunate island, which I called the Island of Despair, all the rest of the ship's company being drowned, and myself almost dead "(Robinson Crusoe, (2009), page 80).

Humanity encounter with alienation and estrangement reveals the individual weakness, separation, despair, void, misery, defenseless, and desired to desolate. These take us to the next characteristic of existentialism that is fear and trembling anxiety.

\section{Fear and Trembling Anxiety}

Christian existentialists, including Kirkegaard, observed human anxiety as bring man to desire salvation. Atheist existentialists see it as a state of despair that indicates man is always oppression by anxiety ((Alssid, 1964, page: 208). Anxiety comes, a man in his life ought to make moral choices that end up with consequences. The choices demand individuals' responsibility has it influence his life and society.

Robinson Crusoe had to make dire choices either to go on his heart desire to voyage in the sea or accept his fathers' call to study law. As supported by Hassan, man is nothing else but what he makes of and decides for himself (Hasan, 1973, page: 93). The choices point is not optional for man, but whatever he decides, he has to be responsible for the consequences. Fear and trembling engulfed Robinson Crusoe as proofed on the following quote;

".... From whence I have since often observed how incongruous and irrational the common 
temper of humanity is, especially of youth, to the reason which ought to guide them in such cases, viz., that they are not ashamed to sin, and yet are ashamed to repent; not ashamed of the action for which they ought justly to be esteemed fools but are ashamed of the returning, which only can make them be esteemed, wise men..." (Robinson Crusoe, 2009, chapter II page: 19).

Parents and children guidance in primitive and present modern society still hold division either to allow youth to make decisions or not. Every person has fear and anxiety when it reaches a situation to choose what to do or follow. The consideration for decision may be hard but need to be of value to self and society. Robinson Crusoe, when struck with the miseries at the rough voyage he made resolutions to consider his father's advice, he refers it as '... goodness of middle station life" where man has no exposure to troubles.

\section{The Encounter with Nothingness}

The situation that a man is alienated from God, from nature, from society, and himself, forces him to a state of Nothingness. Problems and difficulties are prone to encounter a man in one way or the other. The difficulty to find the solution to problems, prompt men to feel nothingness. According to Alssaid (1964), the state of nothingness is a feeling of despair and pessimism. The man thinks his life has been on nothing, where he has no reason for living. Robinson Crusoe encountered nothingness as the book says, he remained in a state of uncertainty where he could not decide which measures to take and what course of life to lead. Crusoe experienced an irresistible reluctance to go back home. (Robinson Crusoe, 2009, chapter II page: 19-20)

Robinson Crusoe's state of feeling desolated, void and separated when he was saved from death in an unknown island without food, clothes, and uncertainty of his life security. Brought him to a feeling of nothingness. On the island, Crusoe lived for a long time where he exercises unlimited freedom. (Robinson Crusoe 2009 page 75-76).

\section{Freedom}

Kierkegaard states that human existence is not static (Dagun, 1990:50). Humanity naturally would progress from possibility to reality. As humans possess freedom, this movement to the development possibly takes place based on oneself. Human existence itself exists in his freedom. Thus, freedom equates to human presence itself (Hasan, 1973:24). Human existence authentication associate with the individual free choices of who and what man will become. Initially, Robinson Crusoe tries to obey his father's instructions for him not to go to sea. His father recommends him to study law then go abroad or see around the world. As seen in the novel, Robinson's thoughts continuously prompted him to do what he desired. Robinson consulted his mother to request his father's consent to allow him to voyage in the sea. Robinson pleaded to voyage if the journey turns out not to work as he expected, he would go no more. However, some days later he decides to run away from his home to voyage (Robinson Crusoe 2009, page 8-9)

Human existence is authentic when one gets to exercise freedom of choice on what and who to become. Aristotle's view that being is existence as existentialism relates much to humanity's freedom. Freedom is essential for a human being, even though he must break his parent instructions, as does Robinson Crusoe. However, human decision and ability to make choices is never complete. In nature, circumstances will subject limitations on position, space, and time of the activity. Therefore, humans ought to exercise 'his' freedom subject to all the compulsions and influences that operate at that point. Thus, one's freedom is always threatened. There many factors that pull human capability to agree with himself on the appropriate decision at that particular moment. Society's values and norms play a major influence on the limitation of the human practice of freedom. Hence, all of the human existence is lived in the tension between limit and freedom.

Kierkegaard in Panjaitan (1996) argue that human realize oneself through the ability to choose freely. He further points on the need for everyone to be an active actor in the field of the situation encountered in the world. To exercise freedom of choice, a man ought to be positive in mind. Robinson Crusoe at the island wrote; 


\begin{tabular}{|c|c|}
\hline EVILS & GOOD \\
\hline $\begin{array}{l}\text { Crusoe stayed in deso- } \\
\text { late island feeling void } \\
\text { and hopeless }\end{array}$ & $\begin{array}{l}\text { Crusoe is alive not } \\
\text { drowned as all his com- } \\
\text { panions }\end{array}$ \\
\hline $\begin{array}{l}\text { Crusoe was separated } \\
\text { from God, humanity and } \\
\text { self yet miserable and } \\
\text { lonely. }\end{array}$ & $\begin{array}{l}\text { He was separated } \\
\text { from death, he was } \\
\text { miraculously spared from } \\
\text { perishing in the sea. }\end{array}$ \\
\hline $\begin{array}{l}\text { I am divided from } \\
\text { mankind, a solitaire, one } \\
\text { banished from human } \\
\text { society. }\end{array}$ & $\begin{array}{l}\text { But I am no starved and } \\
\text { perishing on a barren } \\
\text { place, affording no } \\
\text { sustenance. }\end{array}$ \\
\hline Crusoe had no clothes & $\begin{array}{l}\text { He was in a hot climate, } \\
\text { where he hardly needed } \\
\text { clothes }\end{array}$ \\
\hline $\begin{array}{l}\text { Crusoe was defenceless } \\
\text { in case of violence and } \\
\text { wild beast }\end{array}$ & $\begin{array}{l}\text { But I am cast on an island, } \\
\text { where I see no wild beast } \\
\text { to hurt me, as I saw on the } \\
\text { coast of Africa; and what } \\
\text { if I had been shipwrecked } \\
\text { there? }\end{array}$ \\
\hline $\begin{array}{l}\text { Crusoe's island had no } \\
\text { human to converse with. }\end{array}$ & $\begin{array}{l}\text { But God wonderfully } \\
\text { sent the ship in near } \\
\text { enough to the shore, that } \\
\text { I have gotten out so many } \\
\text { necessary things as will } \\
\text { either supply me wants or } \\
\text { enable me to serve myself } \\
\text { even as long as I live. }\end{array}$ \\
\hline
\end{tabular}

Source: Robinson Crusoe, 2009, chapter VII page:75-76

The thoughts and positivity of Robinson Crusoe made him understand and use his freedom better. However, the freedom individual selects to put as the basis for his decision will have consequences on persons' own miseries of happiness. Both incidences that happen to human has a positive and negative impact. As categorized from Crusoe's experiences as evil and good, the personality attitude on existences tension 'him' between stretching the limits to attain complete practice of one's freedom. The incidences referred to as evil in human existence have equivalent good. Therefore it endorses existentialism.

\section{Conclusion}

The novel Robinson Crusoe by Daniel Defoe plays vital evidence to depict the components of Existentialism in an augmented manner. Robinson Crusoe's character brought the fact that humans are existence. Embrace of human presence gives the desire to being and advance to becoming. As life unfolds, man exercises the ability to make choices even if it means going against the wishes of knowledgeable others. Robinson Crusoe's freedom of choice led him to alienate from man, God, society, and oneself. This state makes him feel nothing, and his life appears to be of no value to live. The start of alienation from man, society, God, and oneself brings fear and trembling. Though all the challenges, difficulties that Robinson come across, he still had freedom, and man's freedom is in his existence.

\section{References}

Abidin, Z. Filsafat Manisha. PT Remaja Rosdakarya, 2002.

Abrams, M. H. A Glossary of Literary Terms, Heinle Heinle Publishers, 1999.

Adian, Donny Gahral. Percik of Contemporary Thought: A Comprehensive Introduction, 2005.

Alssid, Michael and William Kennedy. The World of Ideas: Essays for Study, Holt, Rinehart \& Winston Inc., 1996.

Dagun, S.M. Filsafat Eksistensialisme, Rineke Cipta, 1990.

Defoe, Daniel. Robinson Crusoe, Tiny Tot Publications, 2009.

Endraswara, S. Metodologie Penelitian Sastra, Pustaka, 2004.

Fatmawati, E. A Strike for Freedom as Reflected in Kate Chopin's The Awakening, Surakarta, 2001.

Gilchrist, Roberta. Gender and Material Culture: The Archaeology of Religious Women, Routledge, 1994.

Hardiana, Ratih. Strike for Freedom as Reflected in "Gadis Jakarta" (A Philosophical Approach), Malang, 2005.

Hasan, F. Berkenalan Dengan Eksistensialisme, Pustaka Jaya, 1973.

Hidayat, A.A. Filsafat Bahasa, PT Remaja, 2006.

Kaufmann, Walter. Existentialism from Dostoevsky to Sartre, Meridian Books, 1956.

Lune, Howard and Bruce L. Berg. Qualitative Research Methods for the Social Sciences, Pearson, 2016. 
Muzairi. E. Eksistensialisme Jean Paul Sartre, Stanton, Robert. An Introduction to Fiction, Holt, Pustaka Pelajar, 2002. Rinehart \& Winston, 1965.

Panjaitan, O. Maniais Séparai Eksistensi, Yayasan Strawson, P.F. Freedom and Resentment and Other Subers Agung, 1996. Essays, Methuen \& Co. Ltd., 1974.

Stainback, Susan Bray and William C. Stainback. Woodhouse, Mark B. Berfilsafat: Sebuah Langkah Understanding and Conducting Qualitative Awal, Kanisius, 2007. Research, Council for Exceptional Children, 1988.

\section{Author Details}

Adama Bah, Department of Studies in English, University of Mysore, Mysore, Karnataka, India,

EmailID: bahdamis01@gmail.com 